Mini Review

\section{Challenge of polymers for biosimilar products packaging}

\author{
Anupam Chanda* \\ Packaging and Polymer Science Technologist (PG), India
}

\section{Abstract}

Presently Packaging plays a significant role for Biosimilar product. The process of selecting materials and the type of packaging also offers an opportunity for the Packaging scientist to look for new biological delivery choices. Most injectable protein products were supplied in some sort of glass vial, prefilled syringe, and cartridge. Those product having high $\mathrm{Ph}$ content there is a chance of "delamination "from inner surface of glass vial. With protein-based drugs, the biggest issue is the effect of packaging derivatives on the protein's three-dimensional and surface structure. These are any effects that relate to denaturation or aggregation of the protein due to oxidation or interactions from contaminants or impurities in the preparation. The potential for these effects needs to be carefully considered in choosing the container and the container closure system to avoid putting patients in jeopardy.
More Information

*Address for Correspondence:

Anupam Chanda, B.Sc (Math), Packaging and

Polymer Science Technologist (PG), India,

Email:mr.anupamchanda@rediffmail.com

Submitted: July 08, 2021

Approved: September 28, 2021

Published: September 29, 2021

How to cite this article: Chanda A. Challenge of polymers for biosimilar products packaging. Arch Biotechnol Biomed. 2021; 5: 057-058.

DOI: 10.29328/journal.abb.1001029

Copyright: @ 2021 Chanda A. This is an open access article distributed under the Creative Commons Attribution License, which permits unrestricted use, distribution, and reproduction in any medium, provided the original work is properly cited.

\section{Check for updates}

O OPEn ACCEss

\section{Cause of delamination}

Formulations with a high $\mathrm{pH}$ include phosphate and citrate buffers increase the risk of glass delamination.

$>$ High alkali content in glass could accelerate erosion.

$>$ High temperature during the vial-forming process increase the risk of glass delamination.

Terminal sterilization (irradiated at 20-40 kGy for 150 min) also is a risk factor for specific products(veterinary parenteral administration), could cause delamination.

High product-storage temperatures and long exposure times can increase the rate and severity of glass delamination.

\section{How to prevent delamination}

Treating the surface of the glass vials with materials, such as ammonium sulfate or siliconization can reduce the rate of glass erosion.

Consider alternative sterilization methods only in rare cases.

$>$ The correct specification for the glass to ensure its suitability for the $\mathrm{pH}$ of the product.

$>$ Use COC/COP vial.

- Use of Aluminosilicate glass instead of Borosilicate glass.
Present market demand is syringe barrel and/or plunger coated with silicone. Non-uniform silicone coatings can affect protein stability. The proteins can absorb into the walls of the container. While silicone can reduce absorbtion, excess silicone can form suspended oil-like droplets. Proteins can form around those droplets and change their natural state. New lubricant coatings, such as inert fluoropolymers, are being introduced to replace silicone. As a very inert material, fluoropolymer provides smoothness for the syringe plunger without the irregularities or the issues that have come with silicone. Other new coating materials are being introduced with new types of packaging related to self-injectors, especially injector pens, patches, and transdermal and wearable devices for self-infusion. Extractable and leachable are most important for inhalers and catheters.

For an extractables from a device component the AET $(\mu \mathrm{g} / \mathrm{g})$ can be determined using Equation 1:

$A E T=S C T \cdot D_{t}$

$D_{d} m$

$D_{d}$ - Doses per day

$D_{t}$ - Total Labelled doses

$m$ - mass of component

The AET ( $\mu \mathrm{g} /$ device) for a drug delivery device (e.g. an MDI) can be determined from Equation 2: 


$$
\begin{aligned}
& A E T=S C T \cdot D_{t} \\
& D_{d} \\
& D_{d} \text { - Doses per day } \\
& D_{t}-\text { Total Labelled doses }
\end{aligned}
$$

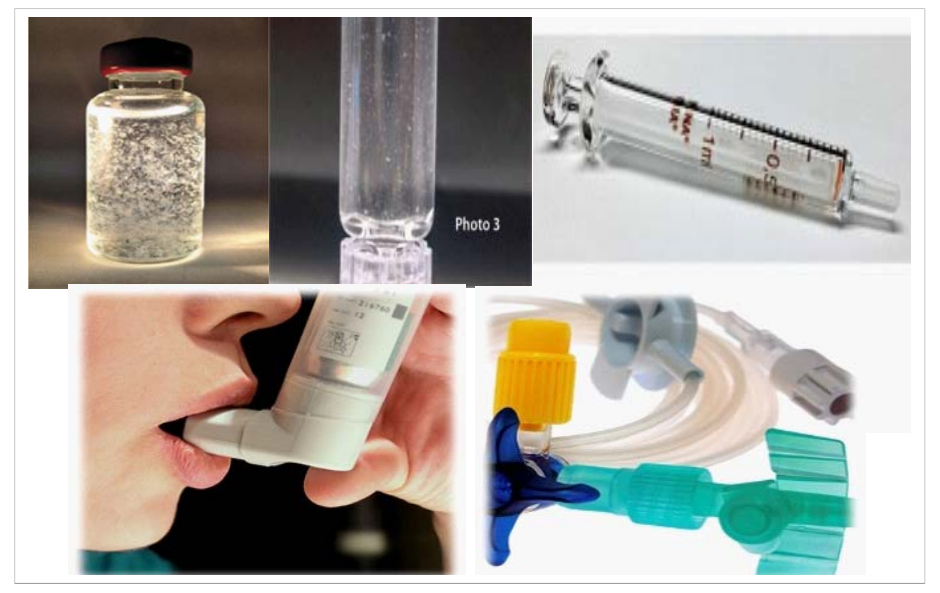

